\title{
DZIENNIKARSKIE ZDJECIA IGRZYSK OLIMPIJSKICH Z LAT 1988-2016 W KONKURSIE WORLD PRESS PHOTO
}

Media masowe od początku funkcjonowania nowożytnych igrzysk olimpijskich stały się ich świadkiem, obrazotwórcą i komentatorem. Wiek dwudziesty przyniósł coraz ściślejszą współpracę organizacyjną między nadawcami medialnymi a organizatorami igrzysk. Ekspansja telewizyjnych transmisji nad innymi kanałami przekazu zaczęła być zauważalna już od 1960 roku, czyli Igrzysk Olimpijskich w Rzymie, ale dopiero w Meksyku w 1968 roku po raz pierwszy zastosowano bezpośredni przekaz o zasięgu ponadkontynentalnym ${ }^{1}$. Jak zauważyła Iwona Loewe, telewizja jako medium wykorzystała olimpiady nie tylko, by promować olimpizm, sport i poszczególne rywalizacje, ale także samą siebie ${ }^{2}$. Pozostałe media, czyli prasa, radio, a z czasem internet, broniły i bronią osobności swoich przestrzeni i stylów komunikacyjnych właściwymi sobie narzędziami opisu, pozwalającymi na odmienne rozpoznania i pozycję odbiorcy niż te, które oferuje strumień telewizyjny. Do takich narzędzi właściwych prasie należy fotografia dziennikarska, współcześnie obecna także w przestrzeni internetu. Zwolniona $\mathrm{z}$ funkcji szybkiego powiadamiania, którym zajmują się media audiowizualne, pozostała dokumentem, ale pozwalającym na o wiele bardziej refleksyjny odbiór.

\section{CEL ARTYKUŁU I ZAKRES MATERIAŁOWY}

Zadaniem, jakie będzie przyświecało dalszym rozważaniom, jest porównanie zdjęć prasowych, które zostały wykonane przez zawodowych fotoreporterów na kolejnych

\footnotetext{
* Dr hab. Magdalena Piechota - Zakład Komunikacji Społecznej, Wydział Politologii UMCS, e-mail: magdapiechota@wp.pl.

${ }^{1}$ Andrzej Ostrowski podaje, że pierwszy telewizyjny przekaz z Igrzysk Olimpijskich w Berlinie w 1936 roku obejrzało 160 tys. widzów, transmisje z Londynu w 1948 roku pół miliona, z Tokio w 1964 roku 600 milionów, a z Meksyku w 1968 roku 720 milionów. Za: A. Ostrowski, Telewizyjna transmisja sportowa czyli największy teatr świata, Wrocław 2007, s. 66.

2 I. Loewe, Igrzyska olimpijskie w polskiej telewizji, [w:] Igrzyska Olimpijskie w mediach masowych: 1948-1984, red. E. Pawlak-Hejno, M. Piechota, P. Nowak, Lublin 2016, s. 16.
} 
igrzyskach olimpijskich w latach 1988-2016. Pierwotnym miejscem publikacji owych fotografii była różnego typu prasa, wydawana przez zatrudniające tych fotoreporterów lub współpracujące z nimi redakcje czy agencje. Następnie zdjęcia zostały zgłoszone do konkursu World Press Photo przez owe redakcje i agencje lub samych fotoreporterów, i wyróżnione przez jury w kategorii Sports. O wyborze tego właśnie konkursu zadecydowała ranga, jaką się cieszy, a także stosunek do zawodowych obowiązków dziennikarzy wizualnych, jaki promuje kapituła tego konkursu od początku jego istnienia. Ponadto nagrodzone zdjęcia zostały uznane za element wizualnej historii igrzysk olimpijskich, gdyż były i są dostępne w corocznych albumach World Press Photo, na stronie internetowej fundacji WPP oraz były pokazywane w ramach wystaw pokonkursowych w wielu krajach. Dodatkowo wyróżnienie nagrodą w konkursie WPP przydało interpretacji zdjęć nową ramę kontekstową, związaną z jednej strony z docenieniem kunsztu fotografów, z drugiej zaś z wyeksponowaniem tematyki, jaką prezentują. Obecność tematyki igrzysk olimpijskich na zdjęciach nagradzanych w badanym okresie potwierdziła założoną $\mathrm{z}$ góry tezę, że ranga tematu w naturalny sposób przyciągnęła uwagę fotoreporterów, a następnie członków jury konkursu. Zasadniczym celem artykułu będzie więc pogłębiona analiza zakresu tematycznego zgromadzonych zdjęć, połączona z refleksją nad sposobami prezentowania poszczególnych zagadnień, a także własnościami kompozycyjno-warsztatowymi poszczególnych fotogramów.

\section{DZIENNIKARSTWO WIZUALNE}

Fotoreporter to dziennikarz wizualny. Jego zadania są tożsame z zadaniami dziennikarzy informacyjnych, tyle że operuje obrazem, a nie słowem. W myśl „,paktu faktograficznego"3 ciążą na nim pewne obowiązki, wynikające ze społecznego zaufania, jakim a priori wciąż obdarzane są przekazy anonsowane jako dziennikarskie. Należą do nich wierność prezentowanym faktom, szczegółowość i zwięzłość. W przypadku fotografii dziennikarskiej wierność wydaje się o wiele łatwiejsza do osiągnięcia niż w przypadku przekazów słownych, ponieważ to rejestracja rzeczywistości, a nie jej opis. Jednak manipulacje obrazami są dziś na porządku dziennym, przede wszystkim dlatego, że powszechnie dostępne programy do ich obróbki pozwalają na stworzenie symulakrycznych wizji ${ }^{4}$, nie mających odniesienia do rzeczywistości, jak to ma miejsce w reklamie. W przypadku prasy, na

${ }^{3}$ Zob. Z. Bauer, Gatunki dziennikarskie, [w:] Dziennikarstwo i świat mediów. Nowa edycja, red. Z. Bauer i E. Chudziński, Kraków 2008, s. 255-262.

${ }^{4}$ Zbigniew Bauer pisał: „Cyfrowy montaż obrazu i dźwięku, dostępny dzisiaj nawet na poziomie amatorskim, stawia pod znakiem zapytania dotychczasowe relacje między światem rzeczywistym a jego obrazem, który przekazują media. Zamiast analogowego wizerunku rzeczywistości pojawia 
przykład cover photo, czyli zdjęcia okładkowe w kolorowych magazynach, a nawet w niektórych tygodnikach opinii, prezentują zazwyczaj taki poziom retuszu czy uzupełnień wyglądu realnej z pozoru osoby, że jej opublikowana wizja jedynie w ogólnych zarysach pozwala na identyfikację, a i z tym może być problem ${ }^{5}$. Dzisiaj obraz w mediach niczego nie gwarantuje w sensie dokumentalnym, nie może być odruchowo i bezwarunkowo traktowany jako ekwiwalent wycinka rzeczywistości, ponieważ jeśli nawet nie został poddany technicznej obróbce, to pośpiech i obniżenie standardów pracy współczesnych redakcji prasowych przyczynia się do wyboru fotografii niejednokrotnie przypadkowych, a nawet amatorskich, czysto ilustracyjnych, ale też tendencyjnych, celowo wykadrowanych, wykonanych z takiej perspektywy, by udowodnić założoną tezę. To nie jest na szczęście wyłączna praktyka, wciąż jeszcze można spotkać profesjonalne, przemyślanie wykonane kadry, z których możemy czerpać wiedzę o współczesności. Właśnie takim obrazom poświęcony będzie ten artykuł.

Można na wstępie przypisać takim zdjęciom pewną ,przezroczystość”, wynikającą ze szczegółowości i zwięzłości ze wspomnianego paktu, zaproponowanego przez Zbigniewa Bauera. Niech oznacza ona brak narzucającej się tezy, która miałaby określać jedynie słuszną interpretację tego, co widać. Proporcje między dokumentarnością i estetyką są wyważone tak, by nie odwracać uwagi od przekazywanych treści, które mamy prawo przyjmować jako obraz tego, co jest. Strona estetyczna jest swoistym dodatkiem, wynikającym z warsztatowych umiejętności fotografa połączonych $\mathrm{z}$ jego wyczuciem i intuicją.

Gdy fotografia została wynaleziona, społeczeństwo przemysłowe XIX wieku zobaczyło w niej idealny sposób na wyobrażanie i przedstawianie samego siebie, dopasowany do: ,poziomu jego rozwoju, techniki, własnego rytmu, do przyjętego modelu społeczno-politycznego, do wyznawanych przez nie wartości i, rzecz jasna, do istniejących w danym momencie możliwości ekonomicznych. W połowie XIX wieku fotografia stanowiła najlepszą odpowiedź na wszystkie te oczekiwania i potrzeby. Dzięki temu znalazła się w samym sercu nowoczesności i dzięki temu również przypisano jej rolę dokumentu. Ten status pozwolił jej uwierzytelniać

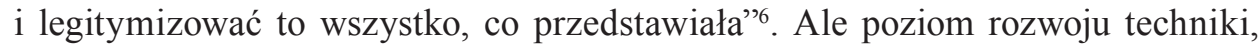
modele społeczno-polityczne, systemy wartości i możliwości ekonomiczne zmieniły się przez te już wkrótce dwieście lat od wynalezienia fotografii na tyle znacząco, by jej mimetyczność rozważać co najmniej na tle jej potencjalnego artyzmu

się jego symulacja: figura wytworzona całkowicie we wnętrzu komputera, sprzężonego z kamerą wideo lub cyfrowym aparatem fotograficznym". Tamże, s. 260.

${ }^{5} \mathrm{Na}$ przykład dziennikarka Monika Olejnik na wielu okładkach kolorowych pism, takich jak „Viva” czy „Uroda”, wygląda na o wiele młodszą niż w rzeczywistości. Z kolei na okładkach tygodników opinii, jak „Newsweek” czy „Wprost” pojawiają się kolaże, wykorzystujące elementy kilku obrazów jednocześnie.

${ }^{6}$ A. Rouillé, Fotografia. Między dokumentem a sztuka wspótczesna, przeł. O. Hedemann, Kraków 2007, s. 23. 
czy przynajmniej autorskiego wyboru obiektu i techniki wykonywania zdjęcia, a także jakże ważnych uwarunkowań kulturowych i technologicznych. Fotografię, na tle strumienia telewizyjnego, wyróżnia jednak wciąż materialność i stałość, więc reprodukowalność, przy jednoczesnej niepowtarzalności punktu widzenia i świadectwie innego stylu percepcji. Jak zauważyła Susan Sontag: „Fotografie mogą zapadać w pamięć mocniej niż ruchome filmy, ponieważ stanowią oddzielne jednostki czasu, a nie jego przepływ. Telewizja - to strumień niestarannie dobranych obrazów, z których każdy wymazuje poprzednika ze świadomości widza. Nieruchoma fotografia - to chwila obdarzona przywilejem trwałości, można ją zamienić w niewielki, płaski przedmiot i oglądać do woli"'

O ile nie zawsze, czy też bardzo rzadko, pamiętamy o operatorze kierującym oko kamery na transmitowane wydarzenia (nawet montaż telewizyjny ujęć z różnych kamer, który teoretycznie powinien nam to uzmysławiać, stał się oczywisty do tego stopnia, że nie ma tej mocy), o tyle podpis fotoreportera pod zdjęciem czy obok niego, a także niezbywalna obecność jego „oka widzącego” w postaci określonego kadru karzą myśleć inaczej o odpowiedzialności za poznawczy efekt zdjęcia w stosunku do ruchomych telewizyjnych obrazów. Fotoreporter współcześnie jest wciąż wcieleniem najlepiej pojętej misji dziennikarskiej, a jego przeciwieństwem byłby podglądający, polujący na sensację i odzierający z intymności paparazzo czy fotoamator, wykorzystujący aparat w swoim smartfonie do uchwycenia przypadkowo ujrzanej sceny, a następnie sprzedający efekt swojego refleksu na licznych platformach służących pozyskiwaniu takich materiałów do wykorzystania w profesjonalnych mediach.

Zbigniew Bauer trafnie podkreślił rolę odbiorcy w każdym typie fotografii. W akcie jego patrzenia dokonuje się odbudowa czegoś, co Walter Benjamin nazwał ,aurą” utrwalonego obiektu, wynikającą przede wszystkim z tego, że „na niego został zwrócony obiektyw aparatu i ukierunkowana wola fotografa - zostaje wyjęty z porządku powszedniości. Przestaje być przedmiotem, staje się obiektem, swoistym partnerem fotografa, umożliwiającym przekaz. Jest to zatem problem wyłączającego potoczność, a zarazem włączającego niezwykłość spojrzenia - nie aparatu przecież, lecz człowieka"». Człowiek-widz dostaje dzięki temu szansę spotkania zarówno $\mathrm{z}$ bohaterem czy miejscem przedstawionym w kadrze, jak i z człowiekiem-autorem tego kadru.

W tej perspektywie konkurs World Press Photo, organizowany od ponad pięćdziesięciu lat przez profesjonalnych fotodziennikarzy i dla nich, jawi się jako swoista enklawa dziennikarstwa jakościowego i zaangażowanego społecznie. Jan Pleszczyński, który określił takie wcielenie mianem dziennikarstwa deontologicznego, wskazał w nim na chęć realizacji dobra wspólnego i dbałość o publiczne zaufanie, przeciwstawiając je dziennikarstwu teleologicznemu, nastawionemu na doraźny

\footnotetext{
7 S. Sontag, O fotografii, thum. S. Magala, Warszawa 1986, s. 21.

${ }^{8}$ Z. Bauer, Dziennikarstwo wobec nowych mediów. Historia Teoria Praktyka, Kraków 2009, s. 71.
} 
zysk ${ }^{9}$. Zwrócił uwagę na fakt, że znajomość zawodowego warsztatu jest warunkiem sine qua non etycznego podejścia do profesji, połączył więc profesjonalne umiejętności, które w przypadku fotodziennikarstwa są najlepiej pojętym rzemiosłem, z etycznym stosunkiem do realizacji stawianych sobie z ich wykorzystaniem celów, a bazą byłaby prawdomówność, rzetelność i uczciwość ${ }^{10}$. Twórcy i organizatorzy konkursu WPP wydają się mieć właśnie takie cele.

FOTOGRAFIA DZIENNIKARSKA - POMIĘDZY DOKUMENTEM A METAFORĄ

Artystyczne aspekty fotografii dziennikarskiej tkwią w jej naturalizmie, w możliwości ukazywania świata w sposób natychmiastowy i względnie szczery. Jednak z drugiej strony zdjęcie prasowe postrzegane jako rzemieślnicza reprodukcja nie jest bezpośrednim „dziełem” artysty, a jedynie efektem użycia w odpowiedniej chwili odpowiedniego sprzętu i dopasowania parametrów. Jak pisze Susan Sontag: „,fotografie nie kojarzą nam się jednoznacznie z zamiarem artystycznym. Zawdzięczają swoje pochodzenie luźnej współpracy (na poły magicznej, na poły przypadkowej) między fotografem a tematem oraz pośrednictwu coraz prostszej i coraz bardziej automatycznej maszyny, która jest niezmordowana i która nawet dzięki kapryśnemu przypadkowi prowadzi do uzyskania wyników na tyle ciekawych, że nie zasługują na wyrzucenie do kosza" ${ }^{\prime 1}$. W przypadku tak emocjonującego widowiska, jakim są zmagania najlepszych sportowców świata, współpraca z tematem chyba nigdy nie ogranicza się do zawodowego rzemiosła. Mając świadomość, że kibice zobaczyli już wcześniej wiele filmowych relacji ze zmagań, fotoreporter może postawić dziś sobie inny cel niż tylko informowanie. Może dokumentować przeżycia i ich momentowe zmiany w nieruchomych kadrach, tym samym odrywając je od czasu i przestrzeni, co czyni je symbolicznymi czy metaforycznymi.

Według Henryka Latosia, obraz fotograficzny „stał się znakiem jak litera, słowo, a nawet zdanie, ułatwiającym porozumienie między ludźmi. Stał się nowym, najbardziej uniwersalnym środkiem przekazu, jednakowo zrozumiałym dla wszystkich, nieznającym barier językowych, narodowościowych, etnicznych, społecznych i kulturowych. W tej uniwersalności tkwi tajemnica powodzenia fotografii jako źródła informacji o otaczającym nas świecie, ludziach i wydarzeniach"12. Warte przy toczenia są także słowa Susan Sontag, którymi określa dostrzeżoną przez siebie, nieoczywistą funkcję fotografii: „Fotografowanie jest równoznaczne z przywłaszcze-

\footnotetext{
9 J. Pleszczyński, Etyka dziennikarska, Warszawa 2007, s. 61-63.

${ }_{10}$ Tamże, s. 31-33.

${ }^{11}$ S. Sontag, s. 53.

${ }^{12}$ H. Latoś, Z historii fotografii wojennej, Warszawa 1985, s. 6.
} 
niem sobie zdejmowanego przedmiotu. Oznacza to wchodzenie w pewien stosunek, która kojarzy nam się z poznaniem, czyli zawładnięciem"'13. Sontag zaznacza, że fotografia nie wymaga od jej autora selekcjonowania obrazów, które chce uwiecznić, tak, jak czyni to malarstwo. Nie udaje się jednak zrobić dwóch identycznych zdjęć tego samego przedmiotu dwóm różnym osobom. Świadczy to o indywidualności postrzegania i wyborów twórczych, nawet jeśli polegają tylko na naciśnięciu spustu migawki. Szybkość obsługi sprzętu i jego coraz bardziej wyrafinowane technicznie możliwości pozwalają na rejestrowanie wszelkich widzianych miejsc, zdarzeń i ludzi, a fotografowie uczynili z patrzenia rodzaj nowego ideału: „zdawało im się, że oglądając świat dostatecznie wytrwale i uporczywie mogą faktycznie pogodzić dążenie do prawdy i potrzebę odkrywania piękna w świecie"14. Gdy patrzenie dotyczy tak widowiskowych, a jednocześnie kulturowo symbolicznych działań jak olimpijskie dyscypliny sportowe, odkrywanie piękna wydaje się dość naturalne. $\mathrm{Na}$ estetycznych, pełnych kolorów stadionach muskularni młodzi ludzie wykonują celowe i precyzyjne działania, dające się pięknie pokazywać. Tyle że to stereotyp, który, w myśl przytoczonych wyżej słów Charliego Riedela warto odrzeć z oczywistości. Praca fotoreportera wymaga wrażliwości i znajomości psychologii, które pozwolą mu dostrzec różnorodność obserwowanych osób i ich przeżyć, a następnie opisać ją za pomocą obrazu.

\section{KONKURS WORLD PRESS PHOTO I SPORT}

Fundacja World Press Photo powstała w 1955 roku, kiedy grupa holenderskich fotografów zorganizowała konkurs, aby zaprezentować swoje prace kolegom po fachu z innych krajów. Jest niezależną organizacją non-profit, której działalność opiera się na pomocy między innymi holenderskiej Postcode Lottery oraz sponsorów, na przykład firmy Canon. Główna siedziba World Press Photo znajduje się w Amsterdamie, gdzie dyrektor Lars Boering zarządza trzydziestoosobowym zespołem ${ }^{15}$.

Celem World Press Photo jest zwiększanie publicznego zainteresowania fotografią prasową oraz podtrzymywanie dyskusji o międzynarodowym rozwoju dziennikarstwa wizualnego i standardów w mediach. Działalność Fundacji koncentruje się na corocznym konkursie World Press Photo, który stara się honorować najlepsze fotografie i fotoreportaże z całego świata. Fundacja pracuje z gronem wybitnych fotografów i redaktorów, ustanawiającym zawodowe standardy oraz oferującym

\footnotetext{
${ }^{13}$ S. Sontag, s. 8.

${ }^{14}$ Tamże, s. 84.

15 World Press Photo, https://www.worldpressphoto.org/about/mission; data dostępu: 20.03.2017.
} 
ćwiczenia dla fotografów, a także zapraszającym do debat nad etycznymi i praktycznymi aspektami fotografii prasowej ${ }^{16}$.

Jednym z podstawowych założeń World Press Photo jest promowanie wizualnego dziennikarstwa. Cele podejmowanych działań, jakie wyznaczają sobie członkowie Fundacji, to inspirowanie do wyrażania obecnych i poszukiwania nowych punktów widzenia, wzmacnianie zaangażowania fotoreporterów w ich pracę, nauka dziennikarstwa i fotografii, a także wspieranie wolności słowa i praw człowieka. Jako najważniejsze wartości, którymi kierują się w pracy, wymieniają: dokładność, bezstronność, sprawiedliwość, szacunek, transparentność oraz odpowiedzialnośćc ${ }^{17}$.

Howard Chapnick - jeden z redaktorów książki This Critical Mirror. 40 Years of World Press Photo - nazywa ofertę Fundacji współczesnym lustrem historii, lustrem różnorodności, służącej jako wizualna biografia przeszłości, historia chwil, kompilacja wydarzeń, które kształtują przeszłość ${ }^{18}$.

Konkurs World Press Photo już od ponad 60 lat skupia uwagę światowej publiczności na znaczeniu fotografii prasowej w dokumentowaniu życia ludzi, przedstawiając co roku zbiór najważniejszych, według jurorów, zdjęć minionych dwunastu miesięcy. Dotychczasowe zasoby fotografii konkursowych stanowią źródło niepowtarzalnych informacji o zmianach zachodzących na świecie, a jedną z głównych kategorii, w których przyznawane są nagrody, jest sport.

Już w tej pierwszej edycji z 1955 roku wygrało zdjęcie z wyścigu motocrossowego, przedstawiające dramatyczny moment upadku kierowcy z pędzącego motocykla, a w edycji z 1956 roku w wyróżnionej po raz pierwszy kategorii Sports nagrodzone zostały trzy fotogramy, przedstawiające: gigantycznego rosyjskiego koszykarza (228 $\mathrm{cm}$ wzrostu), górującego nad pozostałymi zawodnikami (pierwsze miejsce), rywalizację biegaczy Emila Zatopka i Sándora Iharosa podczas Światowego Festiwalu Młodzieży w Warszawie (drugie miejsce) oraz narciarza Tony'ego Sailera, podczas slalomu giganta w trakcie zimowych Igrzysk Olimpijskich w Cortina d'Ampezzo, na których zdobył trzy złote medale.

Należy podkreślić, że zarówno pojedyncze zdjęcie reporterskie, jak i fotoreportaż, z natury gatunkowych własności wykluczają jakąkolwiek aranżację ${ }^{19}$, ponieważ to niepowtarzalność i oddanie sytuacji stanowi o ich wartości. Zadaniem dziennikarza wizualnego jest pokazanie odbiorcy tego, czego być może nie zauważyłby, obserwując dane zdarzenie. Ważna jest także intuicja fotoreportera, gdyż w przeciwieństwie do dziennikarza piszącego nie ma on możliwości opisania sytuacji na nowo. Jego zadanie polega na wnikliwej obserwacji i umiejętności uchwycenia decydującego momentu

${ }^{16}$ S. Mayes (red.), This Critical Mirror. 40 Years of World Press Photo, Thames\&Hudson, New York 1995, s. 218.

${ }^{17}$ World Press Photo, https://www.worldpressphoto.org/about/mission; data dostępu: 20.03.2017.

${ }^{18} \mathrm{H}$. Chapnick, Observations on photojournalism in the second half of 20th century, w: S. Mayes (red.), dz. cyt., s. 9.

${ }_{19}$ Nie było to takie oczywiste w 1936 roku, gdy Leni Riefenstahl aranżowała powtórki zwycięskiego skoku Jessego Owensa na użytek filmu „Olympia”. 
przebiegającego zdarzenia, często w ułamku sekundy. Kenneth Kobré, próbując odpowiedzieć na pytanie, jak poszukiwać ponadczasowych tematów, powołał się na Charliego Riedela, fotografa agencji Associated Press, który za najwyższą wartość fotografii dziennikarskiej uważa możliwość pokazania zwykłej sceny w niezwykłym ujęciu: „Staram się pokazać ludziom rzeczy, których normalnie by nie zobaczyli”" Można to rozumieć jako umiejętność patrzenia niestereotypowo i dużo wnikliwiej niż przeciętny obserwator. Tyle że igrzyska olimpijskie, pomimo swych licznych odsłon, nigdy nie są ,zwykłe”. To zawsze wielkie widowisko z ludzkiego wysiłku, emocji i walki z innymi oraz z samym sobą, oprawione przez wysiłki organizatorów w wiele rytuałów. To globalne święto - a czas sacrum z definicji jest niezwykły. Tym bardziej nie dziwi, że lata, w których odbywają się igrzyska, zarówno letnie, jak i zimowe, przynoszą ogromny zbiór fotografii, publikowanych w prasie na całym świecie, z których pojedyncze zostają nagrodzone w konkursie WPP. Ich wyróżnienie na równi stanowi o profesjonalizmie autorów, jak i randze tematu.

Konkurs World Press Photo wiąże się z surowymi warunkami związanymi z faktograficznością zgłaszanych zdjęć. Fundacja dopuszcza jedynie udział fotografów, którzy bezapelacyjnie stosują się do kodeksu etycznego, sporządzonego specjalnie dla aplikujących. Ponadto, zanim twórca zdecyduje się na udział w Konkursie, oświadcza, że zapoznał się z warunkami udziału, będącymi rozwinięciem punktów kodeksu etycznego.

Podstawowym kryterium udziału w Konkursie jest profesjonalizm. World Press Photo informuje o wymogu posiadania dokumentów takich jak karta dziennikarska, poświadczenie członkostwa w związku profesjonalnych fotografów czy referencje $z$ agencji fotograficznej lub redakcji. Podczas wysyłania zgłoszenia fotograf musi złożyć także oświadczenie, że jest autorem przesyłanych przez niego zdjęć oraz wyraża zgodę na podpisanie ich swoim imieniem i nazwiskiem. Ważnym elementem jest tytuł fotografii, jaki twórca podaje w chwili jej zgłaszania do konkursu. Konieczne jest również zapewnienie, że wykonanie fotografii nie wiązało się ze złamaniem prawa, a także, że zdjęcie nie narusza praw osób trzecich i ewentualne roszczenia wobec nich przyjmuje fotograf.

Zgłaszane zdjęcia klasyfikowane są w jednej z głównych kategorii, które pozostają w miarę niezmienne na przestrzeni lat. Wspótczesne problemy to kategoria, w której fotografie dokumentują aktualną sytuację ekonomiczną, kulturalną, polityczną, społeczną lub środowiskową. Życie codziennie poświęcone jest fotografiom bardziej lub mniej zwykłych elementów i sytuacji codzienności, które rzadko pojawiają się w mediach. Fotografie przekazujące informacje o wydarzeniach oraz ich następstwach zgłaszane są w kategorii Wiadomości ogólne. Jedną z najchętniej wybieranych przez fotografów jest kategoria Ludzie, czyli portrety. Kategoria Sport istnieje od drugiej edycji konkursu i występuje albo jako Sports, albo jako Sports

${ }^{20}$ K. Kobré, Fotografia prasowa. Z obiektywem za kulisami niezwyktych wydarzeń, tłum. M. Lipa, Gliwice 2011, s. 82. 
Action i Sports Feature. Poświęcone są fotografiom sportów indywidualnych lub grupowych oraz obserwacji momentów o charakterze wiadomości lub nagłych wydarzeń o charakterze sportowym. Uczestnicy mogą także zgłaszać fotografie flory, fauny, krajobrazów czy najogólniej mówiąc środowiska naturalnego do kategorii Natura. Do najnowszych należy kategoria Projekt dtugoterminowy, w której zgłaszać można dokonania fotograficzne wykonane przez fotografa indywidualnego lub grupę fotografów, zawierające od 24 do 30 zdjęć.

Skład oceniający zobowiązany jest przyznać w każdej z kategorii pierwszą, drugą oraz trzecią nagrodę, a dodatkowo jednej fotografii nadany zostaje tytuł World Press Photo of the Year, czyli najlepszego zdjęcia roku, wraz z nagrodą finałową. Tytuł ten wyróżnia fotografa, którego dokonanie dokumentuje wydarzenie lub problem znaczące i ważne dziennikarsko w danym roku.

Można stwierdzić, iż najważniejszymi z zasad uczestnictwa są te traktujące o braku manipulacji, zmiany i fałszowania rzeczywistości przedstawianej na fotografiach konkursowych. Organizatorzy oczekują od fotografa szczerości, dążenia do prawdy wyrazu, możliwie jak najbardziej obiektywnej, zaniechania ingerencji w dokumentowane sytuacje oraz jak najdokładniejszego odwzorowania rzeczywistości.

Katalogi World Press Photo, tworzone corocznie od pierwszej edycji Konkursu, niezaprzeczalnie stanowią najlepsze źródło dokumentalne dla każdego, kto chce analizować cechy prasowej fotografii współczesnej i zachodzące w niej zmiany od $1955 \mathrm{roku}^{21}$. Dawniej przejście zdjęcia do kolejnego etapu, aż po ewentualne zwycięstwo, determinowane było przez dziennikarskie znaczenie tematu zobrazowanego na przesłanym zgłoszeniu. Obecnie bardzo istotną rolę odgrywa estetyka fotografii.

\section{NAGRODZONE FOTOGRAFIE Z IGRZYSK OLIMPIJSKICH}

Rozróżnienie sposobów analizy obrazu fotograficznego w przypadku fotografii dziennikarskiej jest dość istotną kwestią. Roland Barthes wyróżnia ich dwa rodzaje. Pierwszym jest studium, oznaczające poznawczą ocenę zdjęcia, z uwzględnieniem odczytania zakodowanych znaczeń, oceny znaków oraz relacji między owymi znakami. Odkodowanie zawartej w obrazie informacji pozwala na zdobycie wiedzy o przedstawianym obiekcie i dokonuje się wobec wcześniej posiadanej wiedzy. Drugą metodą natomiast jest punctum, czyli ocena wpływu fotografii na jej odbiorcę, w pewnym sensie naruszająca studium. Pod uwagę bierze się tutaj nie kwestie techniczne i poznawcze, ale reakcję po zapoznaniu ze zdjęciem, co świadczy o istotnym wpływie elementów obrazu na jego postrzeganie i emocjonalny odbiór.

${ }^{21}$ C. Caujolle, The World Press Photo, the Press and Stereotypes, w: Stephen Mayes (red.), dz. cyt., s. 56 . 
Jak stwierdza Barthes: „Punctum jakiegoś zdjęcia to przypadek, który w tym zdjęciu celuje we mnie"22. To właśnie oddziaływanie fotografii na jej adresata stanowi o empatii fotografa lub jej braku, co warunkuje nie tylko jego umiejętność przekazu informacji, ale też poruszenie nimi widza. Oba typy analizy są w równym stopniu istotne, ponieważ dopiero połączenie przekazu fotografa oraz odbioru adresata nadaje fotografii sens i czyni ją wartościową i znaczącą ${ }^{23}$. W świetle tego rozróżnienia można wyobrazić sobie złożoność kryteriów, decydujących o tym, jakie fotogramy wyróżnia w danym roku jury konkursu World Press Photo.

Susan Sontag już wiele lat temu zauważyła: „Fotografie nie reprodukują rzeczywistości, ale w sposób typowy dla współczesnego społeczeństwa wykorzystują ją jako swego rodzaju surowiec wtórny" ${ }^{24}$. Do czego może posłużyć taka transpozycja fragmentu rzeczywistego świata w przypadku fotografii dziennikarskiej poświęconej igrzyskom olimpijskim? Być może do przekazania niejako w tle, właściwie obok głównego tematu wielu problemów współczesnego świata, które skupiają się jak w soczewce $\mathrm{w}$ tak spektakularnym wydarzeniu, jakim są igrzyska. Z pewnością wiąże się to zarówno ze studium, jak i z punctum, gdy podlega ocenie jury.

Wybór dokonany przez jurorów konkursu autonomizuje nagrodzone zdjęcia, wydobywając je z ich pierwotnego prasowego kontekstu. Nie tylko zaczynają istnieć niezależnie od pierwszego miejsca publikacji, ale dodatkowo od czasu, gdy technologia cyfrowa to umożliwiła, zostają umieszczone w nowej ramie interpretacyjnej, jaką jest kolekcja nagrodzonych fotografii, zebrana na stronie internetowej World Press Photo. Poniższe analizy będą odnosiły się zatem do zdjęć „,wypreparowanych” z naturalnego pierwotnego otoczenia, dostępnych za pomocą strony internetowej konkursu. Pominięty zostanie w nich fakt, że co roku wystawa świeżo nagrodzonych fotogramów objeżdża wiele miejsc na świecie, otwierając przed widzami jeszcze inny model odbioru, związany z bezpośrednim kontaktem z odbitkami, co zasługuje na odrębną analizę, uwzględniającą społeczne i materialne uwarunkowania takich interakcji.

Sport to przede wszystkim ruch. Statyczne zdjęcie wydaje się jego przeciwieństwem. Zamrożenie ruchu odbywa się z udziałem różnych technik, do których należy operowanie ustawieniem ostrości, przysłoną i czasem naświetlania, opracowanie tonalne, panoramowanie, obiektywy szerokokątne i zmiennoogniskowe, zdalne wyzwalanie migawki, tryb sekwencyjny, czyli czysto techniczne parametry, ale także kreacyjny wybór perspektywy (np. z lotu ptaka, żabia), stylu oświetlenia czy planu (daleki, ogólny, pełny, amerykański, średni, półzbliżenie, zbliżenie, detal). Wszystkich tych profesjonalnych umiejętności można się nauczyć, ale nie kluczowego dla fotografowania sportu wyczucia i przewidywania. Do tego trzeba być znawcą poszczególnych dyscyplin, a także, jak zauważa Kenneth Kobré: „Fotograf sportu sam przypomina sportowca. Musi mieć celność bejsbolisty, refleks koszykarza i kon-

\footnotetext{
${ }^{22}$ R. Barthes, Światło obrazu. Uwagi o fotografii, przeł. Jacek Trznadel, Warszawa 1996, s. 47.

23 Tamże, s. 45-47.

${ }^{24}$ S. Sontag, s. 160.
} 
centrację tenisisty. (...) Chcąc osiągnąć sukces w fotografii sportowej fotoreporter musi naśladować pewne zachowania kibiców, jednocześnie unikając zostania jednym z nich. Powinien na bieżąco śledzić wiadomości sportowe, żeby zawsze wiedzieć, którzy zawodnicy są najlepsi i najpopularniejsi, oraz co godnego uwagi ostatnio zrobili’"25. Igrzyska olimpijskie, gromadzące najlepszych z najlepszych, ułatwiają dziennikarzom wizualnym pracę o tyle, że w jednym miejscu i czasie gromadzą wielu mistrzów.

W badanym okresie wzięto pod uwagę czternaście edycji konkursu World Press Photo, podsumowujących lata, w których miały miejsce letnie i/lub zimowe igrzyska olimpijskie. Statystycznie udział tego tematu w nagradzanych pojedynczych fotogramach ${ }^{26}$ prezentuje się następująco:

- dwukrotnie zdjęcia z igrzysk zajęły wszystkie trzy miejsca w kategorii Sports singles, czyli pojedynczego zdjęcia o tematyce sportowej (w roku 1989, czyli po IO w Seulu i w roku 2005, czyli po IO w Atenach; w przypadku edycji z 2005 roku organizatorzy rozdzielili kategorię na Sports Action i Sports Feature, w każdej nagradzając po trzy zdjęcia - w tej drugiej podkategorii zdjęcie z Aten zajęło pierwsze miejsce, czyli łącznie nagrodzonych fotografii o tematyce olimpijskiej było aż cztery na sześć);

- dwukrotnie nagradzane zdjęcia z igrzysk były dwoma z trzech wyróżnionych w kategorii (w roku 1997, czyli po IO w Atlancie, tu pierwsze i drugie miejsce, i w 2009 roku, czyli po IO w Pekinie, tu miejsca drugie i trzecie);

- sześciokrotnie tylko jedno zdjęcie z igrzysk znalazło się wśród trzech nagrodzonych w kategorii Sports (w 1993 r. po IO w Barcelonie, pierwsze miejsce; w 1995 r. po IO w Lillehammer, drugie miejsce; w 2001 r. po IO w Sydney, pierwsze miejsce; w 2003 r. po IO w Salt Lake City, trzecie miejsce; w 2013 r. po IO w Londynie, trzecie miejsce; w 2017 r. po IO w Rio de Janeiro, trzecie miejsce);

- w czterech edycjach z badanego okresu w finale konkursu WPP nie znalazło się żadne zdjęcie z mających miejsce rok wcześniej igrzysk, za każdym razem sytuacja ta dotyczyła zimowych igrzysk olimpijskich (1999 r. po IO w Nagano, 2007 r. po IO w Turynie, 2011 r. po IO w Vancouver i 2015 r. po IO w Soczi).

$\mathrm{Z}$ zaprezentowanego przeglądu wynika, że znakomitą większością wśród zgromadzonych osiemnastu zdjęć nagradzanych w konkursie WPP były te z letnich igrzysk olimpijskich, tylko dwa fotogramy zostały wykonane podczas zimowych igrzysk (w 1995 r. po IO w Lillehammer i w 2003 r. po IO w Salt Lake City). Można to tłumaczyć zapewne wieloma względami: większą widowiskowością i rozmachem letnich igrzysk, trudnymi warunkami pracy fotografów podczas igrzysk zimowych czy większym uwielbieniem tłumów dla lekkoatletów niż dla skoczków czy narciarzy (choć akurat w Polsce wygląda to inaczej od czasów ka-

${ }^{25}$ K. Kobré, s. 105-106.

${ }^{26}$ Do analizy wybrano wyłącznie kategorię singles, z pominięciem kategorii story. Wybór ten został podyktowany odmiennością gatunkową fotoreportażu w stosunku do pojedynczego zdjęcia reporterskiego. Napięcia narracyjne pomiędzy fotografiami ułożonymi w photo story w celowej kolejności wymagają osobnego opracowania. 
riery sportowej Adama Małysza, ale konkurs WPP ma zasięg światowy). Faktem pozostaje, że zimowe dyscypliny olimpijskie są reprezentowane nader skromnie, a oba zdjęcia pokazują skoczków narciarskich.

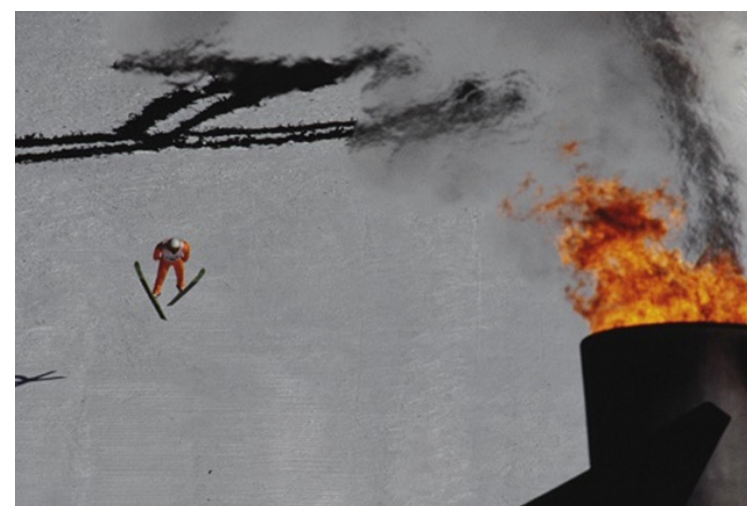

Zdj. 1. https://www.worldpressphoto.org/collection/photo/1995/sports/bill-frakes; dostęp: 18.03.2017; second prize singles w kategorii Sports w WPP 1995, autor zdjęcia: Bill Frazes, USA.

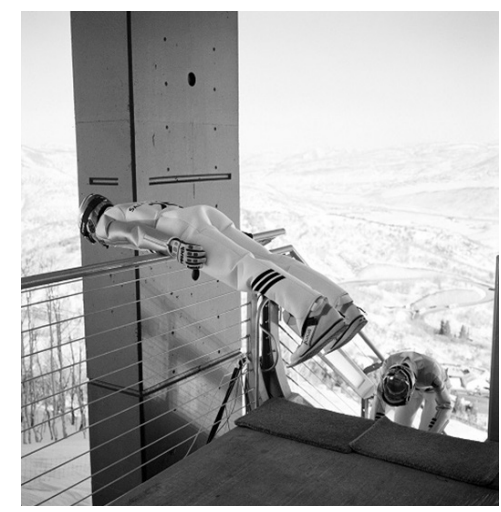

Zdj. 2. https://www.worldpressphoto. org/collection/photo/2003/sports/david-burnett; dostęp: 18.03.2017; third prize singles w kategorii Sports w WPP 2003; autor zdjęcia David Burnett, USA.

$\mathrm{Na}$ obu zdjęciach człowiek jest tylko zawodnikiem, nie mamy dostępu do jego przeżyć, jest szczelnie zakryty kombinezonem i kaskiem, nie widzimy jego twarzy. Pierwsze ze zdjęć ma wyraźnie artystyczny kształt, widać zbieżność kolorystyczną stroju japońskiego skoczka, którego nazwisko nawet nie pojawiło się w podpisie na stronie konkursu, i olimpijskiego płomienia. Niezwykły efekt podwójnego cienia, częściowo rozmytego przez rozgrzane zniczem powietrze (sylwetka skoczka odwzorowana na stoku) i prawdziwego, widocznego po lewej stronie kadru, wprowadza poziome linie, kontrastujące z pionowymi, w których znalazły się sylwetka skoczka i znicz. Skoczek niejako kieruje się w stronę płomienia, oświetlany promieniami słońca, padającymi z prawej strony kadru. Trudno mówić tu o dokumentalnej roli fotografii, zdecydowanie bardziej narzuca się jej symboliczna, a nawet metaforyczna siła. Sylwetka skoczka wydaje się krucha na tle potężnego płomienia, ale unosi się on w powietrzu podobnie jak płomień, do tego pochylona głowa $\mathrm{w}$ rozświetlonym słońcem stalowym kasku wydaje się bardzo dynamicznie celować w przestrzeń, ale i w oko patrzącego. Postać zaprzecza sile ciążenia, wcielając $\mathrm{w}$ czyn ikoniczne przedstawienie widoczne za nim. Siła zdjęcia wydaje się płynąć na równi ze studium, jak i z punctum.

Zupełnie inne pierwsze wrażenie niesie drugi z kadrów. Wykonany podczas przygotowań Michaela Uhrmanna, reprezentanta Niemiec, do skoku na skoczni K120 w Salt Lake City, ukazuje ćwiczenie z użyciem barierki, pomagające zawodnikowi w utrzymaniu ciała we właściwej pozycji podczas skoku. Tym razem 
kadr jest czarno-biały, co podkreśla jego surowość i pozorną techniczność. Jednak czekający na swoją kolej następny zawodnik oraz ośnieżona panorama stanowią kontrapunkty dla skupienia człowieka w piankowym kombinezonie. Jego sprawność w takim kontekście nie wydaje się już tak odhumanizowana. Balansuje w sposób, który dla nieprzygotowanego mógłby okazać się śmiertelny, ale pewność, z jaką to robi, bije z kadru. To uświadamia, że w kostiumie jest człowiek, którego siła woli doprowadziła tu, gdzie jest, a jego decyzje będą za chwilę decydowały o sukcesie lub klęsce w rywalizacji. Zatem i z tego, pozornie chłodnego kadru, można odczytać symbolikę, która być może zdecydowała o przyznaniu mu trzeciego miejsca w kategorii Sports single. Zwykły kibic nie mógłby zobaczyć tej sceny, fotograf zabiera nas za kulisy zmagań, pozwalając być świadkami chwili skupienia i pracy z ciałem.

Zupełnie inne interpretacje można powiązać z dwoma poniższymi kadrami:

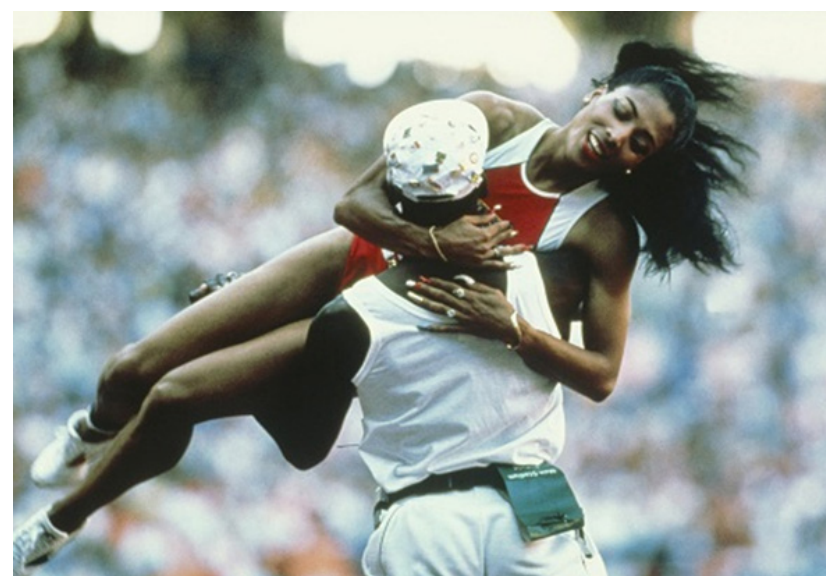

Zdj. 3. https://www.worldpressphoto.org/collection/photo/1989/ sports/lutz-bongarts, dostęp: 18.03.2017; second prize singles w kategorii Sports w WPP 1989; autor zdjęcia: Lutz Bongarts, Niemcy.

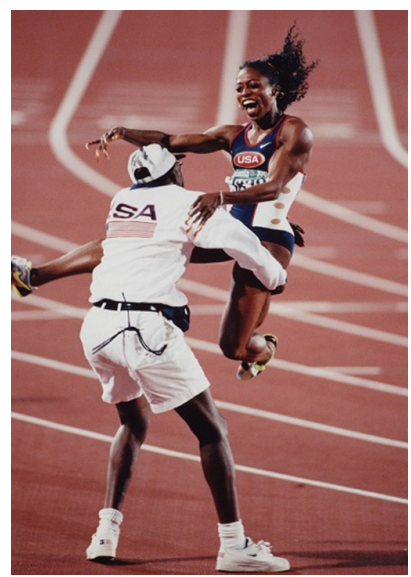

Zdj. 4. https://www.worldpressphoto.org/collection/ photo/1997/sports/stan-behal, dostęp: 18.03.2017; second prize singles w kategorii Sports w WPP 1997; autor zdjęcia: Stan Behal, Kanada.

Na obu fotogramach uchwycony został moment radości po wygranym biegu, dzielony na pierwszym z mężem, na drugim z trenerem. Na zdj. 3 widać bohaterkę Igrzysk Olimpijskich w Seulu, Florence Griffith-Joyner, unoszoną przez męża po zdobyciu przez nią złotego medalu w biegu na 200 metrów i ustanowieniu rekordu świata na tym dystansie. Fokus skierowany na postacie rozmył tło, sprawiając, że mamy wrażenie obcowania z bardzo intymnym momentem dzielonego szczęścia. Przymknięte oczy Griffith-Joyner i spokojny uśmiech nadają jej twarzy wyraz błogości. Mąż z łatwością unosi jej smukłe ciało, co przydaje scenie na równi dynamiki, jak i symboliki połączenia pierwiastka kobiecego i męskiego w idealną całość. Muskularne ramiona biegaczki, obejmujące szyję 
mężczyzny, tworzą zamknięcie odgradzające oczy widzącego od chwili tych dwojga pośród tłumu, który stanowi tylko rozmyte, kolorowe tło. Nie można pominąć widocznych na zdjęciu słynnych bardzo długich i bardzo kolorowych paznokci bohaterki. Między innymi dzięki nim, ale też niezwykłej urodzie, stała się ulubienicą mediów wizualnych. Fotograf Lutz Bongart z Niemiec uchwycił moment, w którym mogła zamiast zwyciężczynią i najszybszą kobietą świata być ukochaną, z której tak bardzo dumny jest mąż.

Na zdj. 4 widać z kolei tryumfatorkę biegu na $100 \mathrm{~m}$ w trakcie Igrzysk Olimpijskich w Atlancie, Gail Divers, w objęciach trenera Boba Kersee. Osiem lat później to ona była najszybszą kobietą świata, która właśnie potwierdziła swój prymat w sprincie po tym, gdy wygrała go ponownie po wcześniejszym sukcesie w Barcelonie. Tym razem fotograf Stan Behal z Kanady utrwalił moment na tle bieżni, co nie intymizuje kadru, jak to było poprzednio, ale czyni go ilustracyjnym. Niezwykła jest poza bohaterki - zdaje się spływać z góry na swego trenera, który próbuje ją uchwycić. Z kadru bije dynamika, sposób ułożenia ciał obu postaci wskazuje na ogromną energię, z jaką porusza się Divers i próbę opanowania tego żywiołu przez Kersee. Podobnie jak w porównywanej fotografii sportsmenka ma rozwiane włosy, ale tym razem nie przydaje jej to romantyzmu, a raczej podkreśla nieuchwytność i zawładnięcie przestrzenią, kpiące z grawitacji. Do podobieństw trzeba natomiast zaliczyć muskulaturę ramion i niezwykłe paznokcie. O ile jednak u Florence Griffith-Joyner, choć bardzo długie, nie raziły ekstrawagancją, raczej przydawały postaci element $\mathrm{z}$ innego porządku niż zawodowy, o tyle u Gail Divers zwracają uwagę ekstremalną długością i wydają się być niebezpieczną bronią, z którą mogą spotkać się plecy trenera. Wreszcie elementem różniącym jest także wyraz twarzy biegaczki - to nie spokojna ekstaza, ale ekstatyczna radość pomieszana z dumą. Oto dwie kobiety, które przekroczyły granice ludzkich możliwości i zastygły w prezentowanych kadrach w pozach tryumfatorek - jedna jakby w półśnie, druga w locie.

Dla porównania warto teraz zestawić ze sobą nagrodzone zdjęcia, których bohaterami są sportsmeni:

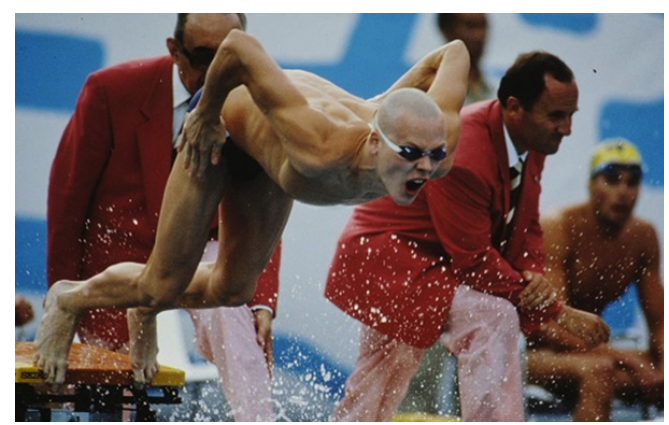

Zdj. 5. https://www.worldpressphoto.org/collection/photo/1993/sports/michael-kunkel, dostęp: 18.03.2017; first prize singles w kategorii Sports w WPP 1993; autor Michael Kundel, Niemcy.

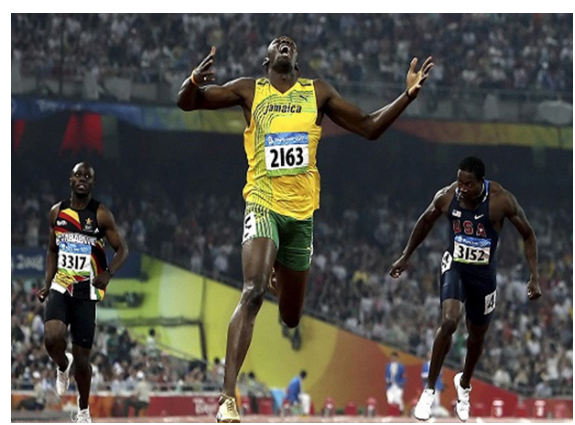

Zdj. 6. https://www.worldpressphoto.org/ collection/photo/2009/sports/mark-dadswell, dostęp: 18.03.2017; second prize singles w kategorii Sports Action w WPP 2009; autor Mark Dadswell, Australia. 
Zdjęcie 5 przedstawia Evgenija Sadovyiego, członka rosyjskiej „zjednoczonej ekipy", utworzonej rok po rozpadzie Związku Radzieckiego. Sadovyi na Igrzyskach Olimpijskich w Barcelonie zdobył trzy złote medale i ustanowił dwa nowe rekordy świata. Kadr prezentuje jego start na 4200 m stylem dowolnym. Zdjęcie gra kontrapunktami - dwaj nieruchomi sędziowie w czerwonych marynarkach stanowią swoistą ramę dla wystrzelającego ze słupka startowego Rosjanina, a widoczny w tle inny zawodnik w żółtym czepku, oczekujący biernie na swoją kolej, wtapia się w rozmyte tło. Ruch podkreślony jest widocznymi w dolnej połowie kadru kroplami wody, wzbitymi zapewne przez zawodnika z toru obok. Sadovyi sprawia wrażenie „maszyny do pływania” - na jego bardzo szczupłym ciele nie widać grama tłuszczu, mięśnie napięte w ruchu wyraźnie rysują się pod skórą, ogolona głowa aerodynamicznie schowana jest $w$ ramionach, wygiętych w sposób przypominający płetwy czy skrzela. Wyraźnie bledsza od reszty ciała twarz wykrzywiona jest grymasem determinacji do walki, a szeroko otworzone usta wydają się chwytać powietrze. Duże dłonie i stopy dopełniają obrazu ciała wykreowanego do jednego celu - wygranej. Punctum tego zdjęcia jest twarz absolutnie zdeterminowanego człowieka, który za ułamek sekundy przestanie być hamowany przez powietrze i znajdzie się w swoim żywiole, w wodzie. Kontrasty między statycznymi i dynamicznymi elementami zdjęcia fundują dramaturgię tego obrazu. Choć są na nim ludzie, trudno myśleć o nich jako o niezależnych jednostkach. Są częścią systemu, któremu na imię igrzyska, każdy wypełnia przypisaną mu rolę.

Podobna trójkowa kompozycja znalazła się na zdjęciu 6, ale to nie moment startu, a finisz. Widzimy Jamajczyka Usaina Bolta, zwyciężającego w biegu na 200m na Igrzyskach Olimpijskich w Pekinie i ustanawiającego nowy rekord świata. Na tych igrzyskach został pierwszym człowiekiem, który w ramach jednej olimpiady ustanowił trzy nowe rekordy (oprócz wspomnianego także na $100 \mathrm{~m}$ i w sztafecie na cztery razy sto metrów). Po raz drugi Bolt na finiszu pozwolił swojej radości zwycięstwa wziąć górę nad pragmatyzmem. Cztery dni wcześniej, dobiegając do mety na $100 \mathrm{~m}$ lekko zwolnił i podniósł ręce w geście tryumfu. Na prezentowanym zdjęciu widać podobne zachowanie - Usain Bolt jest tak pewny swojej przewagi, że całym ciałem wyraża tryumf nad rywalami, a może i nad samym sobą. „Błyskawica", bo tak brzmi pseudonim Bolta, znów idealnie wykonał zadanie. Wszystkie trzy postacie są w ruchu, ale obramowujący głównego bohatera przeciwnicy tworzą drugi plan. Trzecim planem jest widownia, już nie tak rozmyta jak na zdjęciu numer 3, ale nadal pozbawiona jakiekolwiek tożsamości. Widać tylko wypełnione trybuny, a ich elementy konstrukcyjne, ozdobione materiałami w kolorach pomarańczowym, żółtym i zielonym, tworzą idealny komplet z kolorami stroju Bolta, porządkując kadr. Plan pełny zastosowany w fotografii pozwala zauważyć, że wszyscy trzej biegacze jeszcze nie dotknęli bieżni, unoszą się nad nią, ale to Usain Bolt odrywa się od niej szybując ku górze, dwaj pozostali sprinterzy już się ku niej chylą. Ekstatyczna radość bije z pozy bohatera pierwszego planu, skumulowana w odrzuconej do tyłu głowie, ustach otwartych w okrzyku, rozpostartych dłoniach, obejmujących 
niewidzialną kulę, i w naprężonych od wysiłku mięśniach nóg. Bohater sprawia wrażenie, jakby zaraz miał wyskoczyć na oglądającego, by do niego zakrzyknąć: „Hej, czy widzisz?! Wygrałem!!!”. Autor tej fotografii, Mark Dadswell z Australii, zamknął w niej najczystszą energię sportowca-zwycięzcy.

Fotografie sportowe nie zawsze jednak prezentują tryumfatorów, co można zauważyć także w przypadku konkursu WPP. Kadry ukazujące sportowców z dalekich miejsc w klasyfikacji, wnoszą do medialnego obrazu igrzysk jakże ludzki wymiar porażki. Choć często można usłyszeć, że w przypadku olimpiady liczy się już sam udział, trudno uznać to za pocieszenie czy alibi. Wygranych jest niewielu, to rzesza tych, na tle których błyszczą zwycięzcy, czyni sport olimpijski masowym. Rytualne zrównanie nastąpi wraz z ceremonią zakończenia igrzysk, gdy wszyscy, podobnie jak na otwarciu, będą maszerować ramię w ramię. Ale zanim to się stanie, będą musieli wypełnić swoją rolę mistrzowskich statystów.

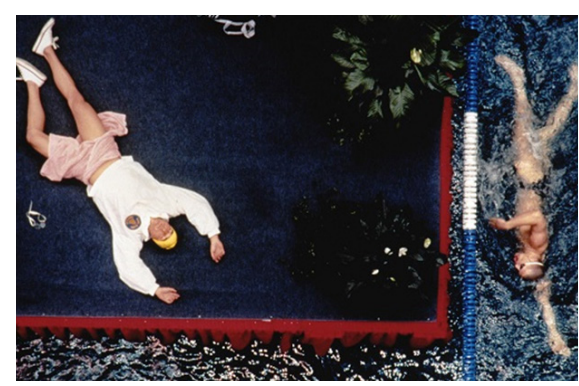

Zdj. 7. https://www.worldpressphoto.org/collection/photo/1997/sports/erich-schlegel, dostęp: 18.03.2017; first prize singles w kategorii Sports w WPP 1997; autor Erich Schlegel z USA.

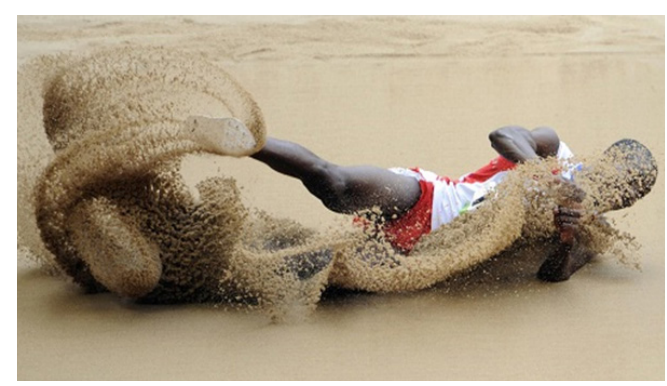

Zdj. 8. https://www.worldpressphoto.org/collection/photo/2009/sports/franck-robichon, dostęp: 18.03.2017; third prize singles w kategorii Sports Action w WPP 2009; autor Franck Robichon, France.

Obie fotografie przedstawiają zawodników, którzy nie dotarli na szczyt. Na zdjęciu 7 Gregg Schaffer odpoczywa na platformie przed startem na 200m stylem mieszanym w czasie eliminacji na Igrzyskach Olimpijskich w Atlancie, które przegrał. Po prawej stronie kadru widać innego pływaka, korzystającego z czasu na trening. Gregga Schaffera oddziela od niego nie tylko zupełnie inny poziom energii, ale nawet linka wyznaczająca tor i spore kwiaty ustawione na platformie. W pozie Schaeffera jest coś dziecinnego: leży bardzo swobodnie, z rękami rozrzuconymi nad głową i rozluźnionymi nogami. Żółty czepek i ciepła bluza zakrywają znaczną część jego ciała, kontrastując z rozchylonym różowym ręcznikiem, którym się opasał. Okulary pływackie leżą w sporej odległości od bohatera, jakby nie chciał mieć ich pod ręką. Ma zamknięte oczy i beznamiętny wyraz twarzy. Czy przegrał, bo nie trenował przed startem? Kadr wydaje się zaprzeczać skojarzeniom, że udział w igrzyskach, choćby na etapie eliminacji, to ciągła walka i determinacja. Fotograf z lotu ptaka utrwalił obraz swoistej inercji, buntu przetrenowanego ciała, które domaga się odpoczynku. Przez punkt widzenia, z którego Erich Schlegel 
wykonał to zdjęcie, Schaffer dla oglądającego ułożył się do góry nogami. To podkreśla abstrakcyjność sytuacji, w której zamiast walczyć do końca, wybiera odpoczynek.

Drugi z kadrów prezentuje odmienną sytuację, właśnie walki do końca. Niezwykle dynamiczna fotografia robi artystyczne wrażenie dzięki pióropuszowi piasku, który swoim skokiem wzbił Kubańczyk Ale Copello. Fotoreporter Franck Robichon z Francji zatrzymał w kadrze czysty ruch - obraz nie do zauważenia przez ludzkie oko, ale do zamrożenia przez migawkę. Copello wydaje się walczyć $\mathrm{z}$ jęzorem piachu jak z potworem, który wspiął się aż ku jego twarzy. Układ rąk wygląda jak próba uchwytu za szyję piaskowego stwora, a jego gęsty jęzor w okolicach stóp pożera zawodnika. Piękny plastycznie kadr oddaje walkę człowieka nie z potworem z piachu, ale samym sobą. Al Copello przegrał kwalifikacje do finału w trójskoku mężczyzn dwoma centymetrami. Największy wróg Kubańczyka okazuje się tak mały, że niewidzialny. Abstrakcyjnego klimatu dodaje zdjęciu perspektywa, z której zostało wykonane. Dziennikarz European Pressphoto Agency zrobił je z takiego poziomu nad ziemią, że piach wydaje się otaczać zawodnika aż po horyzont. Nie widać żadnej publiczności, sędziów, ani innych startujących. Jest tylko skoczek i piach, który chce go pochwycić.

Oprócz zdjęć portretowych, przedstawiających pojedynczych sportowców, w konkursie nagradzane są te, na których widać rywalizację w ramach grupy:

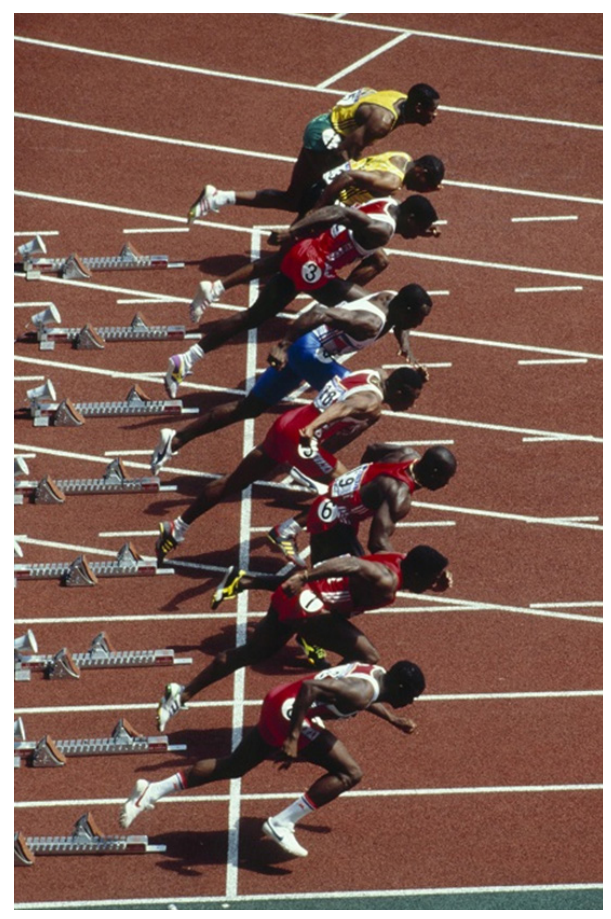

Zdj. 9. https://www.worldpressphoto.org/collection/photo/1989/sports/yann-guichaoua, dostęp: 18.03.2017; third prize singles w kategorii Sports w WPP 1989; autor Yann Guichaoua z Francji.

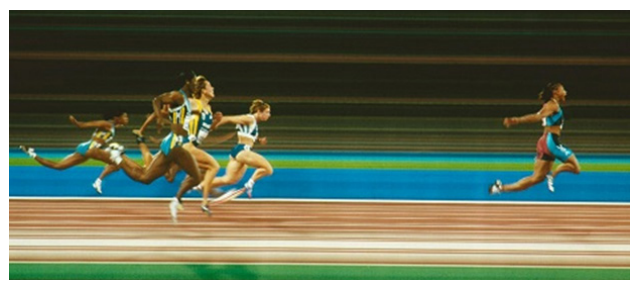

Zdj. 10. https://www.worldpressphoto.org/collection/photo/2001/sports/david-callow-bill-frakes, dostęp: 18.03.2017; first prize singles w kategorii Sports w WPP 2001; autorzy David Callow \& Bill Frazes z USA. 
Na zdjęciu 9 Yannowi Guichaoua z Francji udało się uchwycić dzięki perspektywie z góry, jak Ben Johnson na torze szóstym pokonał już na starcie rywali w biegu na 100m w czasie Igrzysk Olimpijskich w Seulu. Fotografia pokazuje skalę doskonałości wszystkich zawodników, reagujących na strzał startera, i ten ułamek sekundy, o który doskonalszy od nich okazał się Johnson, wysuwający głowę poza linię głów rywali i oddalający stopę od bloków szybciej niż oni. Smutnym kontekstem tego zdjęcia, wiele mówiącym o śrubowaniu rekordów kosztem zdrowia sportsmenów, jest fakt, że Ben Johnson został pozbawiony złotego medalu po odkryciu w jego organizmie niedozwolony środków dopingujących.

Rywalizacja kobiet ze zdjęcia 10, która miała miejsce w trakcie Igrzysk Olimpijskich w Sydney w sprincie na $100 \mathrm{~m}$, to historyczny moment w historii sportu. Wygrywająca Marion Jones pokonała rywalki o 0,37 sekundy, co okazało się drugim wynikiem przewagi na tym dystansie na przestrzeni nowożytnych olimpiad. O ile zdjęcie 9 jest przede wszystkim ilustracyjne i chwyta fascynujący dowód mikroprzewagi Johnsona, która dała zwycięstwo, o tyle zdjęcie 10 poprzez zastosowanie panoramy i zamknięcie w kadrze chwili oderwania od ziemi wszystkich zawodniczek symbolizuje zarówno zwycięstwo „fruwającej” Jones, jak i pozorne zwolnienie z praw fizyki całej grupy biegaczek.

Warto jeszcze odnieść się do fotografii odsłaniających nieoczywiste strony olimpizmu:

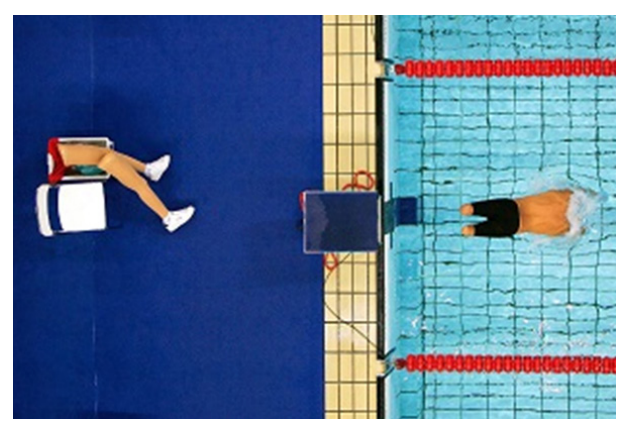

Zdj. 11. https://www.worldpressphoto.org/collection/photo/2005/sports/bob-martin, dostęp: 18.03.2017; first prize singles w kategorii Sports Action w WPP 2005; autor Bob Martin, Wielka Brytania.

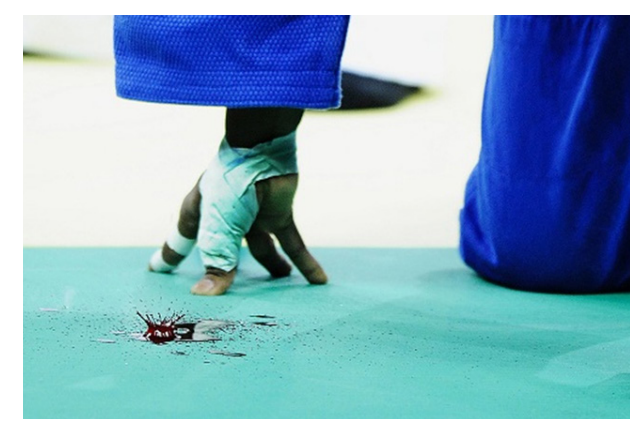

Zdj. 12. https://www.worldpressphoto.org/collection/photo/2009/sports/wu-xiaoling, dostęp: 18.03.2017; first prize sigles w kategorii Sports Feature w WPP 2009; autor Wu Xiaoling, Chiny.

Połączone tym razem zdjęcia mają podobną tonację kolorystyczną, błękity i turkusy, ale zupełnie inną rolę czerwieni. Zdjęcie 11 ukazuje Aviego Torresa z Hiszpani w czasie Igrzysk Paraolimpijskich w Atenach. Startuje na dystansie 200m stylem dowolnym, na którym zajął szóste miejsce, ale na tych samych igrzyskach zdobył srebro i brąz na innych dystansach. Pływanie jest jedną z najważniejszych dyscyplin na paraolimpiadach. Dopuszcza różne ułatwienia dla niepełnosprawnych sportowców, 
z wyjątkiem protez, dlatego Torres zostawił plastikowe nogi obok krzesła i wskakuje do wody gładko się w nią wślizgując. Obraz jest bardzo graficzny, a przez to pełen symboliki. Kolory podłogi i wody wraz z jasnożółtym otokiem niecki tworzą trzy pionowe pasy o proporcjach jak okładka książki odłożonej grzbietem do góry. Platforma startowa spina przestrzeń lądu i wody, stając się miejscem przejścia z niepełnosprawności w pełną sprawność. Dwie wyraźne czerwone linie plastikowych granic między sąsiadującymi torami pływackimi dają znakomity kolorystyczny i geometryczny kontrapunkt dla pionowego kształtu „grzbietu książki”. W tym uporządkowanym świecie z linii jak z obrazów Jerzego Nowosielskiego człowiek i jego sztuczne przedłużenie rozdzielili się, aby to, co ludzkie, czyli siła i wola, wzięły górę nad tym, co nieruchome i chwilowo bezużyteczne. Zdjęcie opowiada o granicach i ich przekraczaniu w sposób subtelny i dyskretny, a jednocześnie dający do myślenia.

Kadr drugi jest przykładem zastosowania detalu. Wu Xiaoling utrwalił na nim mistrzowsko ułamek sekundy, gdy na Igrzyskach Olimpijskich w Pekinie z czoła judoczki Ange Mercie Jean-Baptiste z Haiti skapnęła spora kropla krwi, rozbryzgując się przed klęczącą zawodniczką w trakcie walk przedeliminacyjnych. Obraz także ma bardzo ciekawe proporcje i kolorystykę, kropla jak mała fontanna przełamuje czerwienią turkus maty, z niebieskim strojem zawodniczki i bielą podłogi w tle. Cichy, niewidoczny dla wielu dramat bólu rozgrywa się tylko pomiędzy bohaterką zdjęcia, symbolizowaną przez owiniętą do walki dłoń w pozycji podpierającej i okiem fotoreportera. Zatrzymał w obrazie coś tak gorącego i płynnego jak krew, estetyzując ją w sposób bliski zdjęciom reklamowym. Tyle że warto przypomnieć, że zdjęcia w konkursie World Press Photo nie mogą być retuszowane, radykalnie kadrowane czy inscenizowane. Tym bardziej rośnie podziw dla wrażliwości i spostrzegawczości fotoreportera, który wydobył tę chwilę z przebiegu walki.

Jeszcze jedno znamienne zestawienie zdjęć mistrzów, których nazwiska zapisały się w historii sportu:

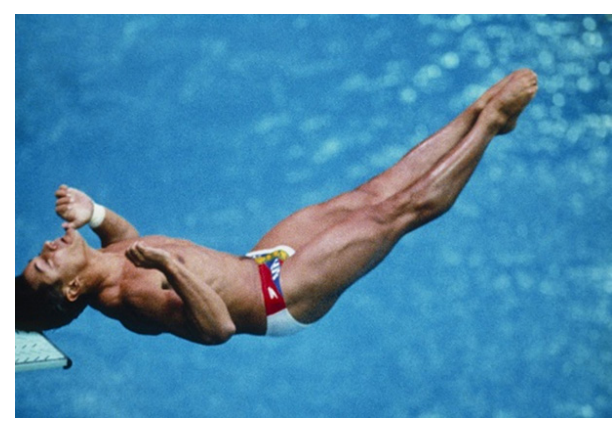

Zdj. 13. https://www.worldpressphoto.org/collection/photo/1989/sports/brian-smith, dostęp: 18.03.2017; first prize singles w kategorii Sports w WPP 1989; autor Brian Smith z USA.

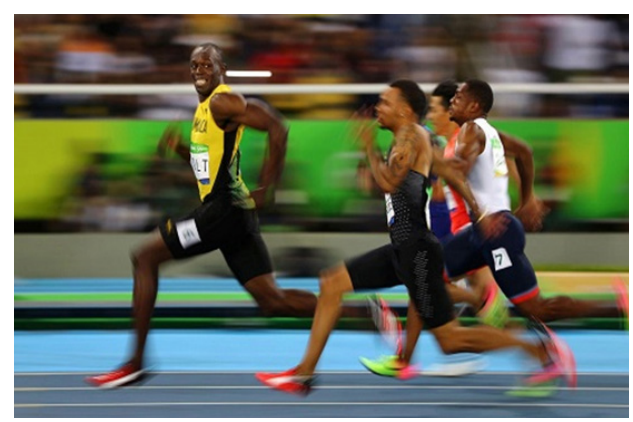

Zdj. 14. https://www.worldpressphoto.org/collection/photo/2017/sports/kai-oliver-pfaffenbach, dostęp: 18.03.2017; third prize singles w kategorii Sports w WPP 2017; autor Kai Oliver Pfaffenbach, Niemcy. 
Pierwszy z kadrów to zwycięzca w swojej kategorii w pierwszym roku z badanego okresu, czyli 1989 (edycja po IO w Seulu), zaś drugi to zdjęcie, które zajęło trzecie miejsce w ostatniej edycji z 2017 roku, zrobione w trakcie IO w Rio de Janeiro. Te dwa zdjęcia to klamra, dobrze obrazująca zmiany, jakie zaszły przez te prawie trzydzieści lat, tak bogate $\mathrm{w}$ wydarzenia polityczne, przemiany społeczne i postęp technologiczny. Widoczny na pierwszym z nich skoczek do wody, Amerykanin Greg Louganis, został sfotografowany w momencie, gdy uderza głową o platformę do skoków. Znalazł się w wodzie z krwawiącą raną, co nie przeszkodziło mu zdobyć ostatecznie dwóch złotych medali za skoki z wieży i z platformy. Widać, że zdjęcie nie jest zbyt ostre, ale jego dokumentalna rola okazała się ważniejsza od pozostałych parametrów. Z kolei drugi kadr to przykład możliwości współczesnych aparatów fotograficznych, ale przecież nie tylko. Aby uchwycić Rio's golden smile (takim podpisem opatrzono zdjęcie na stronie World Press Photo) niemiecki fotoreporter Kai Oliver Pfaffenbach musiał śledzić obiektywem biegnącego Usaina Bolta i zastosować panoramę ze skomplikowanymi parametrami, aby uchwycić ten wyraz twarzy zwycięzcy półfinału na $100 \mathrm{~m}$, pokonującego dystans w czasie 9,86 sekundy. Rozmyte w tle trybuny i nieco niewyraźni rywale stanowią tylko tło dla najszybszego człowieka świata, po którym nie widać cienia wysiłku, więcej, stać go na obejrzenie się na rywali i uśmiech tryumfu. Zwycięstwo sportowego ducha czy perfekcjonizmu? A może biologicznych uwarunkowań, czyniących z Bolta „Błyskawicę”? Zdjęcie nie daje odpowiedzi, ale zaprasza do refleksji.

Wśród zgromadzonych fotografii $\mathrm{z}$ badanego okresu są jeszcze kadry z wyraźnymi brakami technicznymi, niedoświetlone czy ziarniste, ale chwytające w niepowtarzalny sposób przełomowy moment w historii sportu ostatnich lat czy emocje sportsmenów:

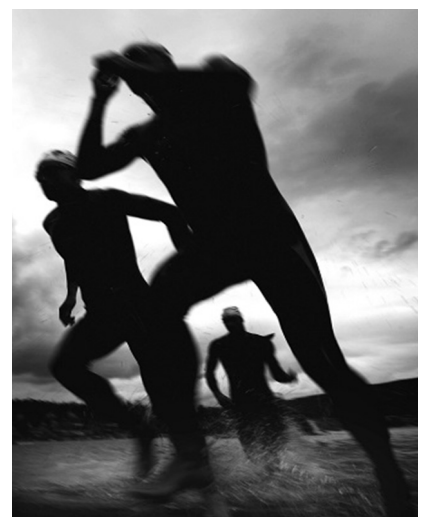

Zdj. 15. https://www.worldpressphoto.org/collection/photo/2005/ sports/jonathan-ferrey, dostęp: 18.03.2017; third prize singles w kategorii Sports Action w WPP 2005; autor Jonathan Ferrey z USA.

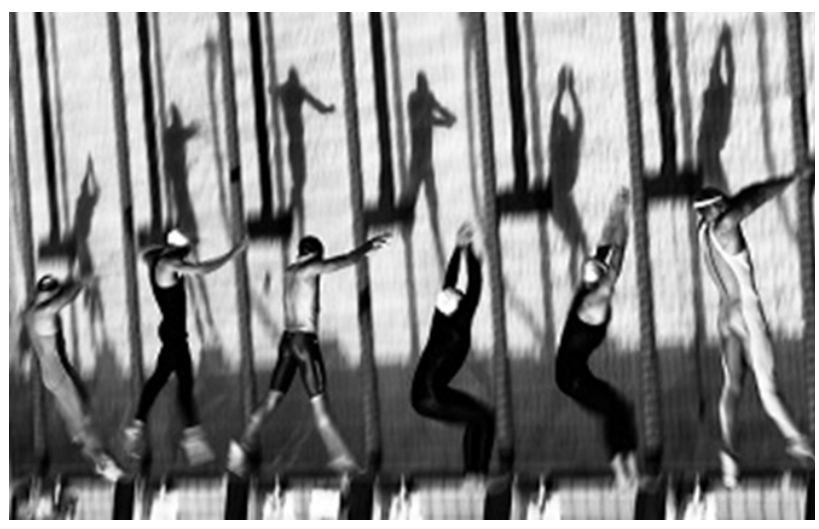

Zdj. 16. https://www.worldpressphoto.org/collection/photo/2005/ sports/adam-pretty, dostęp: 18.03.2017; first prize singles w kategorii Sports Feature w WPP 2005; autor Adam Pretty z Australii. 
Pierwszy z kadrów to obraz wysiłku anonimowych triatlonistów, walczących w amerykańskich zawodach o zakwalifikowanie się na Igrzyska Olimpijskie w Atenach. Przy tym etapie sportowych zmagań nie ma jeszcze wielu ekip dziennikarskich, można więc uznać, że obraz Jonathana Ferreya w unikalny sposób dokumentuje czas pracowitych prób zasłużenia na miano olimpijczyka. Wysiłek trójki zawodników, raczej domyślny niż wyraźnie widoczny, w ciekawie został wydobyty niedoświetleniem i brakiem ostrości. Natomiast drugie ze zdjęć pokazuje historyczny moment obrania odmiennego stylu startu przez Iana Thorpa i Pietera van den Hoogenbanda podczas wyścigu na 200m stylem dowolnym w trakcie tych samych Igrzysk Olimpijskich w Atenach. Pozornie zostają w tyle, ale za ułamek sekundy rozprężone ciała pozwolą im wyprzedzić rywali. $\mathrm{Na}$ obu fotografiach sportowcy są odrealnieni przez brak ostrości. Zdjęcia bardziej niż ludzi pokazują ideę rywalizacji.

Wreszcie ostatnimi kadrami do porównania są wizerunki dwóch zawodniczek w typowo kobiecych dyscyplinach, gimnastyce artystycznej i pływaniu synchronicznym:
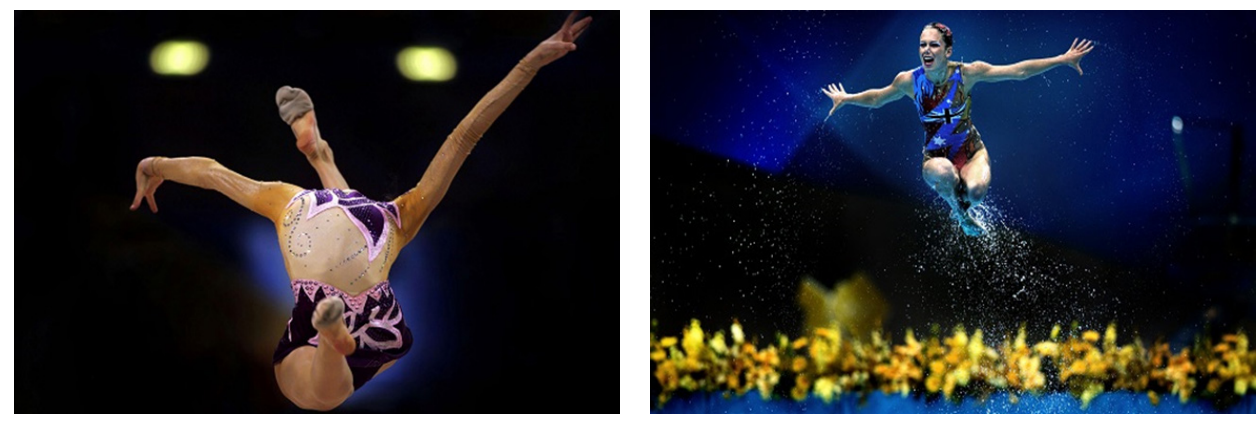

Zdj. 17. https://www.worldpressphoto.org/col- Zdj. 18. https://www.worldpressphoto.org/colleclection/photo/2005/sports/lars-moeller, dostęp: 18.03.2017; second prize singles w kategorii Sports Action w WPP 2005; autor Lars Meller, Dania. tion/photo/2013/sports-action/wei-zheng, dostęp: 18.07.2017; third prize singles w kategorii Sport Action w WPP 2013; autor Wei Zheng, Chiny.

Porównywane kadry dzieli osiem lat, a łączy podobna tonacja kolorystyczna i uchwycenie piękna ruchu. Widoczna na pierwszym ,bezgłowa” wskutek perfekcyjnego wykonania ćwiczenia zawodniczka to Elisabeth Paisieva z Bułgarii na Igrzyskach Olimpijskich w Atenach, gdzie zajęła dwunaste miejsce. Wydaje się bardziej rzeźbą niż człowiekiem, a błękitna poświata od rozmytego w tle reflektora obejmuje jej korpus jak kokon. Wraz z dwoma żółtymi punktowymi światłami, kontrapunktującymi układ rąk i nogi, daje to abstrakcyjną kompozycję, w której sprawność zawodniczki, celującej stopą w oczy widza, jest kluczowym warunkiem uzyskanego efektu, ale dużo bardziej niż sportową formę odbiera się z tego zdjęcia wrażenie abstrakcyjnego piękna. Na pewno wpływ na to ma nieobecność twarzy - bez niej sportsmenka jest raczej obiektem niż osobą. 
Drugi z kadrów to podwodne zdjęcie członkini australijskiego zespołu startującego w pływaniu synchronicznym na Igrzyskach Olimpijskich w Londynie z efektem w postaci ostatniego miejsca w klasyfikacji. I tym razem nierealne piękno czyni fotografię bardziej estetycznym obiektem niż dziennikarskim dokumentem. Kontrast barw oraz poza zawodniczki kojarzą się z bohaterką kreskówki w stylu „Małej syrenki”. Rozproszone światło i girlandy powietrza w wodzie dopełniają feerycznego efektu.

\section{WNIOSKI}

Zastosowana w części analitycznej metoda porównawczej interpretacji pozwoliła na uchwycenie różnorodności tematycznej i technicznej zdjęć wybranych spośród nagrodzonych w konkursie World Press Photo. Dowiodła, jak nośnym i wieloznacznym w odbiorze medium pozostaje fotografia reporterska, utrwalająca obrazy igrzysk olimpijskich. Zachowując w kadrach chwile umykające oku wielu bezpośrednich widzów, śledzących przede wszystkim dramaturgię rywalizacji, a tym bardziej niejednokrotnie niedostępnych widzom przed telewizorami, utrwala w swojej materialności ogromne spektrum znaczeń związanych z ideą olimpizmu, przemianami w rozumieniu sportu i społecznej roli sportowców, ale też z rozwojem cywilizacji.

Konkurs World Press Photo, najbardziej prestiżowa rywalizacja zawodowych dziennikarzy wizualnych, zajmujących się fotografią reporterską, przynosi co roku historię świata w obrazach. Zgromadzone dzięki dzisiejszym możliwościom internetu zasoby zdjęć nagradzanych od 1955 roku do dzisiaj, stanowią nieocenioną kopalnię wiedzy o człowieku wobec otaczających go wyzwań: piekła wojen, które sam sobie zgotowuje, chwil szczęścia i niewyobrażalnych dramatów, samotności i życia z innymi i dla innych, niszczenia przyrody i walki o jej zachowanie, a także wielu innych. Wśród tych setek odsłon historii świata jest sport, jedna z najważniejszych dziedzin życia społecznego, odbijająca jak w soczewce osiągnięcia ludzkości i zgotowane jej przez samą siebie patologie. Obecność igrzysk olimpijskich jako subtematu w tej dziedzinie okazała się łatwo potwierdzalną tezą. Dużo istotniejszym efektem przeprowadzonych badań stały się obserwacje na temat roli fotoreporterów we współtworzeniu współczesnego jakościowego dziennikarstwa. Niewątpliwie sport w postaci igrzysk olimpijskich jest dzisiaj wszystkim: polityką, biznesem, rozrywką, kulturą, modą, widowiskiem, rytuałem. Dzięki dziennikarzom wizualnym w potoku słów, które przy tej okazji padają, obok tabel rekordów i enumeracji nazwisk, obok newsów i komentarzy, obok nieustannego potoku obrazów i dźwięków, mogą pojawić się niezapomniane kadry, mówiące o naszych czasach więcej niż tysiąc opowieści, a do tego w języku zrozumiałym dla każdego - w języku obrazu. Pokazują determinację i rezygnację, szczęście i rozpacz, ból i ekstazę, spokój przygotowań i eks- 
plozję startu, wygranych i przegranych, zmienność obyczajów i wyglądu, a zarazem niezmienność uniwersaliów. Przechowują emocje, odsłaniają chwile intymne, choć dziejące się na scenie, która ma wielomilionową widownię. Magia i siła fotografii dziennikarskiej okazuje się nie mniejsza niż fotografii artystycznej - może dlatego, że sport w olimpijskim wydaniu to sztuka życia herosów, a obrazy tej sztuki mają w sobie niemal zawsze wieloznaczność i wartą zgłębienia symbolikę. Fotoreporterzy świadkują jej, wchodząc z obiektami swoich ujęć w niezwykłe relacje i dowodząc, że dziennikarstwo deontologiczne ma do zaoferowania we współczesnym świecie skomercjalizowanych i stabloidyzowanych mediów jakości i wartości, którym nigdy nie będą w stanie sprostać ci, dla których najważniejszy jest zysk.

\section{BIBLIOGRAFIA:}

Barthes R., Światlo obrazu. Uwagi o fotografii, przeł. Jacek Trznadel, Warszawa 1996.

Bauer Z., Gatunki dziennikarskie, [w:] Dziennikarstwo i świat mediów. Nowa edycja, red. Z. Bauer

i E. Chudziński, Kraków 2008, s. 255-280.

Bauer Z., Dziennikarstwo wobec nowych mediów. Historia· Teoria· Praktyka, Kraków 2009.

Kobré K., Fotografia prasowa. Z obiektywem za kulisami niezwyktych wydarzeń, tłum. M. Lipa, Gliwice 2011.

Latoś H., Z historii fotografii wojennej, Warszawa 1985.

Loewe I., Igrzyska olimpijskie w polskiej telewizji, [w:] Igrzyska Olimpijskie w mediach masowych:

1948-1984, red. E. Pawlak-Hejno, M. Piechota, P. Nowak, Lublin 2016, s. 11-28.

Mayes S. (red.), This Critical Mirror. 40 Years of World Press Photo, Thames\&Hudson, New York 1995.

Ostrowski A., Telewizyjna transmisja sportowa czyli największy teatr świata, Wrocław 2007.

Pleszczyński J., Etyka dziennikarska, Warszawa 2007.

Rouillé A., Fotografia. Między dokumentem a sztuka wspótczesną, przeł. O. Hedemann, Kraków 2007. Sontag S., O fotografii, tłum. S. Magala, Warszawa 1986.

\section{Streszczenie}

Celem artykułu jest pogłębiona analiza tematyczna zdjęć fotoreporterskich wykonanych przez dziennikarzy wizualnych z całego świata, które zostały nagrodzone w kategorii Sports w poszczególnych edycjach konkursu World Press Photo, a wykonano je w trakcie letnich lub zimowych igrzysk olimpijskich w latach 1988-2016. Badania wykazały, że w dobie dominacji transmisji telewizyjnych ze zmagań olimpijskich fotografia dziennikarska została częściowo uwolniona od prymarnego zadania informowania, a zostało ono uzupełnione poszukiwaniem symbolicznego wymiaru wydarzeń olimpijskich. Posługując się teorią Rolanda Barthesa o istnieniu w każdym zdjęciu jego studium i punctum, autorka poddała analizie osiemnaście fotografii, zestawiając je w znaczące pary. Analizy dowiodły, że nagrodzone w WPP zdjęcia wykonane w trakcie kolejnych igrzysk olimpijskich, od Seulu po Rio de Janeiro, przechowały najróżniejsze ludzkie emocje i zachowania, czyniąc z nich emblematy sensu sportowego wysiłku.

Słowa kluczowe: dziennikarstwo wizualne, zdjęcie fotoreporterskie, World Press Photo, sport, obrazy igrzysk olimpijskich 


\section{JOURNALISTIC PICTURES OF THE OLYMPIC GAMES FROM THE YEARS 1988-2016 IN THE WORLD PRESS PHOTO CONTEST}

\section{Sum mary}

The article aims to investigate themes in photographs taken by visual journalists from around the world. The analysed images have received awards in the Sports category of the World Press Photo Contest, and were taken during the Summer and Winter Olympic Games in the years 1988-2016. Research has demonstrated that at a time when the games are predominantly televised, photojournalism has to some extent become liberated from its informational role. In sports coverage, this form of journalism has thus begun searching for a symbolic dimension of the Olympiads. Basing on Roland Barthes's theory that every photograph has a studium and a punctum, the author of the article studies eighteen images, which she arranges into matching pairs. The analysis shows that the award-winning photographs, taken during the Olympic Games from Seul to Rio de Janerio, successfully encapsulate a wide range of human emotions and behaviour, a quality which transforms these images into emblems of athletic effort.

Keywords: visual journalism, photojournalism, World Press Photo, sport, images of the Olympic Games 